\title{
Local Economic Development (LED), Challenges and Solutions: The Case of the Northern Free State Region, South Africa
}

\author{
Dr Daniel Francois Meyer
}

\author{
North-west university (nwu), south africa
}

Email:daniel.meyer@nwu.ac.za

\author{
Doi:10.5901/mjss.2014.v5n16p624
}

\begin{abstract}
Local economic development (LED) should be everybody's business, including local residents, local business people and government. LED is globally, but especially in developing countries, seen as the solution to improved quality of life, unemployment, poverty and inequality. LED is a relatively new field of research and policy formulation, planning processes and implementation plans are still evolving with various alternative theories and approaches. This article analyse LED theory and approaches with a focus on South Africa, with a case study on the northern Free State region. Five municipalities in this region were analysed in terms of their LED approaches, planning and implementation. The research methodology is based on a qualitative approach which includes a literary review and various interviews with role players in the area. Results include solutions, lessons learnt and generic strategies for LED. LED processes could achieve its promise of ensuring improved quality of life if $L E D$ strategies are formulated for effective implementation.
\end{abstract}

Keywords: Local economic development, challenges, solutions, strategies, northern Free State.

\section{Introduction}

"Suitable economic policies could cure all economic problems by stimulating local economic development to create better human and financial capital flows" (Reich, 1991). "Creating new jobs and developing human capacity are not easy tasks. Local institutions and national policy makers must align local human and natural resources of the community to match both global and regional markets, and they can strive to create new jobs that fit both the local people and the place" (Blakely and Bradshaw, 2002).

Globally, academics, development practitioners and stakeholders recognise the important role of local economic development (LED) in order to create jobs, alleviating poverty and improvement in quality of life. In order to achieve dynamic local development, all aspects of local communities such as the economy, social, welfare, environmental and political issues need to be addressed in an integrated and holistic manner. A comprehensive strategy therefore needs to be compiled for a specific region to achieve developmental success (Rogerson, 2009).

According to Rodrigues-Pose (2001), traditional macro-economic policies have in the past been not being successful in creating an enabling developmental environment at the local level and LED has provided an alternative to development. Rodrigues-Pose (2001) listed the following advantages of LED over traditional economic policies namely, LED empowers and ensures local participation, local people can play an active part in planning their own economic future, LED ensures that local business are involved in the process and are more open to play an active role in partnerships with local communities. In addition, LED ensures that local development is locality based and focused on local comparative advantages, it allows for more resilient local economies and LED could create local opportunities and local jobs, thereby improving the local quality of life.

South Africa's current development policy is focussed on "developmental" local government and with a "pro-poor" emphasis. Local government has been pro-actively encouraged through the Constitution (1996) to intervene and to play a leading role in job creation and reduction of poverty through LED. The main constraints in delivering results in "pro-poor" implementation are poor analysis of local economies, unsustainable community projects, lack of capacity and lack of resources (Nel \& Rogerson, 2005).

Both concepts of "pro-poor" and "pro-growth" need to be addressed as an integrated LED policy approach. A progrowth policy could be equated to creating an enabling environment for economic development while "pro-poor" policy equates to poverty alleviation through job creation and social-welfare safety nets (Nel \& Rogerson, 2005). According to Blakely and Bradshaw (2002), the two main approaches to LED include a corporate centred approach with a focus on 
formal business and industrial development, and an alternative approach with a focus on the poor section of a community. Whatever the approach, LED policy should focus on an increase in the number and variety of job opportunities and diversification of economic activities. Local government need to assume an active role in this process (Blakely \& Bradshaw, 2002).

In this article, the functioning of LED at the local government sphere in South Africa will be analysed. The hypothesis is that if a LED strategy is well formulated and is effectively implemented, it can facilitate the acceleration of the creation of jobs and improve quality of life of local people. LED in the northern Free State region (also known as the Fezile Dabi District Municipality region) will be analysed by means of qualitative research and an attempt will be made in the formulation of solutions for improved LED implementation.

\section{Local Economic Development (LED) Defined}

LED forms part of the micro-economic component of development economics. According to Lewis (1966), "development economics is not very complicated as the secret to successful economic development planning lies in sensible politics and good public administration". Development economics is focused on the economic, cultural and political requirements to effect fast institutional reform so as to distribute the benefits of economic progress to the broadest section of the population, thereby ensuring that the poverty trap is broken. In order to achieve this, government intervention by means of policy formulation is needed as a component of development economics. The World Bank (1991) describes development economics as a process to improve quality of life, especially of the poor. This calls for higher incomes but also other important aspects such as better skills and education, higher standards of health and nutrition, cleaner environment, equal opportunities, individual freedom and rich cultural life, leading to less poverty. According to Soedjatmoko (1985), "development theorists have paid insufficient attention to institutional and structural problems and to the power of historical, cultural and religious forces in the development process".

In the literature there are many definitions of LED. Blakely (1994) defines LED as the process with which local government or community-based organisations engage to stimulate or maintain business activity and/or employment. The key role local government has to play in LED can also be found in the definition of Scheepers and Monchusi (2002) who define LED as a process managed by municipalities in accordance with their constitutional mandate to promote social and economic development. According to the International Labour Organization (ILO, 2006), local economies need to find solutions and alternatives to improve and strengthen local competitiveness and comparative advantages to compete on a global scale. The challenge of LED is to find ways to maximize local resources and local knowledge to benefit all inhabitants within a specific geographical area. Trousdale (2005) defines LED is a participating process where local people, from all sectors within a specific area, work together to activate and stimulate local economic activities, with the aim to ensure a resilient and sustainable local economy. According to Bartik (2003) LED is defined as the local economy's capacity to create wealth for local residents.

Meyer-Stamer (2008) defined LED as the ability of a specific area or locality or even region to generate increasing income and improve local quality of life for its residents. LED attempts to remedy market failures such as to remove barriers to enter markets for small business and availability of information. LED is also about creating positive conditions for business development (Meyer-Stamer, 2003). According to Swinburn et al (2006), LED is a process whereby public, business and non-governmental sectors work collectively as partners to create a better quality of life for local residents through economic development. To conclude with regards to an LED definition, LED is the total of all economic activities by all relevant stakeholders within a specific defined geographical region, working together in partnership to create economic development and ultimately improvement of quality of life for all residents in the area.

LED has become a global concept that is generally utilized to address poverty and to create jobs in urban and rural localities. The greatest potential for development support exists at the local government level, with a focus on attracting investments, creating jobs and boosting demand. In South Africa, since 1994, local government's role has expanded from providers of public goods and basic social services to include LED (Local Government Support Program in ARMM, 2009).

\section{Local Economic Development (LED) in South Africa}

Improved local governance performance regarding LED requires cooperation and partnerships. The service delivery triangle relating to LED consists of three partners namely government, private sector and local communities (Meyer, 2013). Figure 1 provides an illustration of the service delivery triangle for LED. 
Figure 1: Service delivery triangle regarding to LED

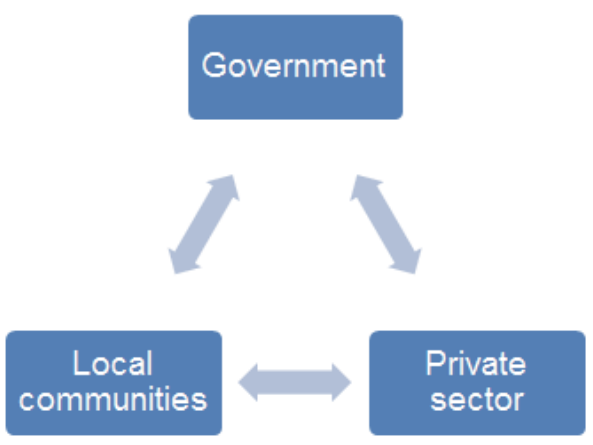

Source: Meyer, (2013).

Various pieces of legislation and policy form the foundation of LED in South Africa. The Constitution (no.108 of 1996) is the foundation and provides for a developmental model of local government. Local government is not only responsible for service delivery, but also for socio-economic development of its communities. In terms of Sections 152 and 153 it is stated that "municipalities must provide and manage their administration, budgeting and planning processes to give priority to the basic needs of communities" (Republic of South Africa, 1996). In terms of the Constitution, local government needs to fulfil the following functions (IIED, 2000; Republic of South Africa, 1996):

Provide democratic and accountable government for all communities,

Ensure service provision in a sustainable way.

Promote social and economic development.

Promote a safe and healthy environment.

Encourage community participation and involvement in matters of the area.

The constitutional mandate has been strengthened by the White Paper on Local Government (1998), which formally introduced the concept of developmental local government. This policy document defines developmental local government as "local government committed to working with citizens and groups within the community to find sustainable ways to meet their social, economic and material needs, and improve the quality of their lives. Furthermore this document makes it quite clear that local government is not responsible for creating jobs, but instead it is responsible for creating an enabling environment for development (Triegaardt, 2007). According to Rogerson (2009) this enablement has laid the foundation for the development of a customised model to drive LED at local government level.

Another important policy initiative is the 2005 "Policy Guidelines for Implementing Local Economic Development in South Africa", which identifies economic growth and poverty eradication as the key overarching goals of LED (DPLG, 2005). Noteworthy is the LED framework Stimulating and Developing Sustainable Local Economies which was released by the Department of Provincial and Local Government in 2006 (DPLG, 2006). The Framework emphasises that municipalities have a key role in creating an environment conducive for investment through the provision of infrastructure and quality services, rather than by developing programmes and attempting to create jobs directly.

Within the 5 year Local Government Strategic Agenda and Implementation Plan (2006), LED has been identified as one of the five key performance areas (KPAs) of local government. According to Van der Heijden (2008) it is important to realise that LED as an outcome is strongly interrelated and dependent upon the other four KPAs, namely, municipal transformation and organisational development, basic service delivery, municipal financial viability and management and good governance and public participation.

LED in South Africa is concerned with creating robust and inclusive local economies that exploit local opportunities, address local needs and contribute to natural development objectives such as economic growth and poverty eradication. The challenge of LED in South Africa is that most local municipalities do not have adequate economic growth strategies in place that are implementable and therefore are unable to address poverty and unemployment. For LED to be successful there should be a coherent planning process involving all stakeholders within the local area. The process takes place over time, involving all sections of the community and covers all matters that affect quality of life in a local area, particularly those that need most support (Sekhampu, 2010).

In order for LED to be more effective in South Africa, the following principles are proposed by Meyer-Stamer 
(2003): the creation of a clear distinction between LED and community development initiatives, refrain to solve problems by throwing money to the problem, ongoing analysis of local economic sectors and address market failures, stimulate entrepreneurship and business development, maximize existing local resources such as finance, natural resources, and human skills by the utilization of mentors, identify and implement "quick wins" projects and creation of a strong partnership between public and private sectors. According to Blakely and Bradshaw (2002), a municipality can decide to act as a developer and even an entrepreneur, a coordinator, a facilitator or a stimulator. The views of these LED specialists regarding the role of local government are supported by ASA-LGP (2005) and DPLG (2003).

Finally, LED success regarding implementation is dependent on six key issues according to Trousdale (2005):

Local leadership at local government, local business and local communities.

An enabling economic environment must exist with access to opportunities for all.

The local youth must be involved through youth development programmes.

Job creation potential must exist, relating to sustainable jobs.

Good governance.

Availability of capacity and skills on all levels of the local economy.

All efforts must lead to poverty alleviation and improvement in quality of life.

\section{Case Study: The Northern Free State Region}

The northern Free State region has been identified as the case study region to determine the extent to which LED has been successfully implemented. The study area has been selected firstly due to its rural character, and secondly due to its strong economic linkages with Gauteng province. The region consists of the Fezile Dabi District Municipality and four local municipal areas namely Mafube, Metsimaholo, Moghaka and Ngwathe local municipalities.

In an interview with Dr A. Venter, LED manager of Fezile Dabi District Municipality on 4 April 2014, current challenges regarding LED in the region were discussed. The district municipality has to play a co-ordination role and assist local municipalities in the area with training and capacity building. The four local municipalities are currently struggling with political instability and capacity challenges. LED units are either non-existent or not fully operational and existing LED strategies are not ready for implementation. Possible provisional solutions to the challenges are LED skills development and capacity improvement. Existing LED strategies need to be adjusted for implementation. Improved cooperation and co-ordination between the district and local municipalities must be facilitated. The district is currently engaged in the establishment of a regional LED forum for the area to improve coordination (Venter, 2014). The municipal entities are illustrated in Figure 2.

Figure 2: Municipal entities in the northern Free State

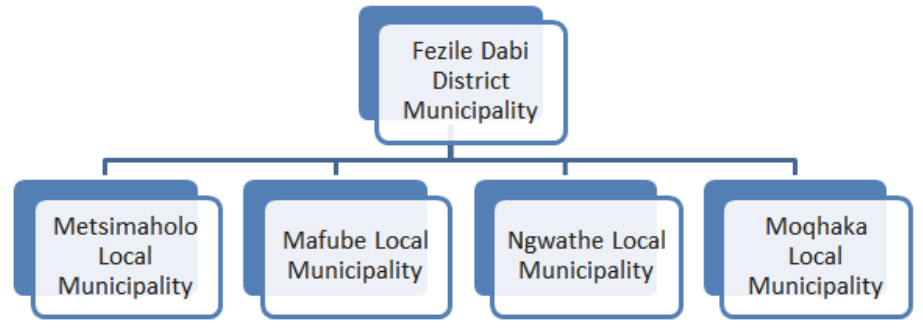

Source: Own compilation.

The methodology used in this article is based on qualitative methods. Interviews were held with all LED managers in the study region and the all the municipalities were analysed regarding the overall structure, the LED unit structure, functionality of the LED unit, and weaknesses and opportunities per municipal area. The following section is a summary of the overview of the municipalities in the study region.

\subsection{Fezile Dabi District Municipality}

The area known as the northern Free State, is bounded to the north by the Vaal River and includes natural features such 
as the Vaal Dam, and the Vredefort Dome area. Main urban areas include Sasolburg, where the administrative node is, Kroonstad, Parys, and Frankfort. The region could be classified as a mostly rural area. Municipal departments include: Office of the Municipal Manager, Finance, Corporate services, Community health and environment, Project management and Public Works and lastly Social Development and Tourism. The LED unit is located in the last mentioned department. A LED unit exists, but needs strengthening. Most of the municipal committees are operational. Good relations exist with provincial departments and all the local municipalities. No regional services plans are in place and no marketing or tourism plans exist. The municipality will struggle to implement the action plans as listed in the LED strategy due to a lack of funding, lack of capacity and a lack of skills. Improved overall support and co-ordination is required by the District Municipality regarding the local municipalities in the region (Meyer, 2013).

Regional government's roles are to ensure investment in the region, and to ensure regional-wide cooperation and collaboration. Regional governments (such as district municipalities) can serve to facilitate LED efforts by acting as an intermediary between national and local government. Provision of infrastructure and environmental improvements are important (Swinburn et al, 2006).

According to the 2011/2012 Integrated Development Plan (IDP) of the district municipality (Fezile Dabi District Municipality, 2012) LED is one of the main objectives for the district municipality. A new LED strategy has been compiled, taking into account all the principles of a modern strategy and is currently being implemented. Funding for implementation is however very limited.

\subsection{Moghaka local municipality (Moghaka means "crown")}

The area forms the south-western boundary of the study area, while the N1 freeway, which links Johannesburg with Cape Town, bisects the area. The municipal headquarters is located in Kroonstad/Moakeng. Other main urban centres are Vijoenskroon/Rammulotsi and Steynsrus/Matlwangtlwang urban. The region could be classified as a rural area, some 2 to 4 hours drive from the closest metropolitan area. Municipal departments include: Office of Municipal Manager, Financial Services, Community and Emergency services, Corporate Services, and Infrastructure Services. The LED unit forms part of the Community Services Department (Meyer, 2013).

LED capacity is very limited and only two officials are responsible for LED. No marketing takes place within the municipality. Only a few small community projects are attempted by LED officials. A LED/IDP forum and Tourism forum exist but are not fully operational. A local business chamber exists and is functional, with good relations with the municipality. Good relations exist with the district municipality. The LED strategy was compiled in 2011, but is very generic and not implementable. Services master plans are outdated and need updating. No marketing or investment plans exist. Huge infrastructure backlogs exist and local political conflict makes the operation of the municipality difficult especially with a lack of strong local leadership. The LED section lacks capacity, skills and sufficient budget to implement action plans. The municipal area is well located for business and industrial development along the N1 freeway for a mixed use development zone. The area is also well located for agro processing and industrial sites are available. Tourism potential also exists in the area. Due to the fact that the area has a strong agricultural sector, irrigation projects need to be implemented.

In the terms of 2010 COGTA (2010) turn-around strategy, challenges in the municipal area were listed as ageing infrastructure and lack of funding for maintenance, lack of technical skilled officials, poor public participation, no performance management system (PMS), poor relationships between political and administrative leaders, poor financial management systems, and lack of LED strategy and LED unit. Solutions to improve the situation include municipal infrastructure grant (MIG) funding, deployment of technical support by the Development Bank of South Africa (DBSA), finalise a public participation policy, national assistance with financial management, and COGTA must assist with the establishment of a LED unit (COGTA, 2010).

In terms of the 2011/2012 IDP, the LED priority sectors are tourism development, agriculture, mining, manufacturing and commercial transport. Poverty alleviation strategies include food gardens, small, medium, micro enterprises (SMME) development and support and cooperatives (Moghaka LM, 2010). The LED objectives for the area are active farming development projects including agro-processing projects, development of SMME's and entrepreneurs, promotion of industrial development, tourism development, poverty alleviation projects, mining development, and food security schemes (Moghaka LM, 2010:). The key strategies included in the LED strategy are spatial integration strategies, infrastructure development, institutional structures, strengthening of the local economic base, SMME's support and development, improve the business environment and improved quality of life (Moghaka LM, 2010). 


\subsection{Mafube local municipality (Mafube means "dawning of a new day")}

The area forms the eastern part of the region, with the Vaal River forming its northern boundary. The N3 freeway, which links Johannesburg with Durban, bisects the municipal area. The municipal headquarters is located in the Frankfort/Namahadi area. Other urban areas include Villiers/Qalabotjha, Cornelia/Ntswanatsatsi and Tweeling/Mafahleng. The region could be classified as a rural area, some 2 to 4 hours drive from the closest metropolitan area. Municipal departments include: Office of the Municipal Manager, Finance, Corporate services, Infrastructure, Community services, Human Settlement, Town Planning and LED, IDP and PMS. The LED unit is located in the last mentioned department. A LED unit does not exist. One IDP/LED Manager is in charge of LED operations. The municipality is planning to appoint tourism and agricultural officers and thereby establishing the LED unit. An LED forum is also planned. No formal local business forum/chamber exists. Good relations between the municipality and the provincial departments and the District municipality exist. Services master plans does not exist as well as no marketing plans. The municipal area has poor economic linkages, with a lack of information, huge housing backlogs and no SMME development plans. Potential exists for large scale agricultural projects, infrastructure development and tourism development along the Vaal River. Developmental opportunities also exist at Villiers along N3 corridor (Meyer, 2013).

In terms of the 2010 COGTA (2010) turnaround strategy, the following challenges were listed for the municipal area namely poor maintenance of roads and infrastructure, lack of housing data base and housing development, poor management system for community development workers (CDW's) in the area, high turn-over levels of staff, poor financial management, and lack of an LED unit with development strategies. Solutions are listed as support by DBSA and MIG funding to development infrastructure, funding to support ward committees and CDW's, assist municipality with salary packages for top employees, national government assistance with improved financial control, COGTA to assist with set-up of LED unit (COGTA, 2010). The Mafube LED strategy was compiled in 2012 (Mafube LM, 2012).

\subsection{Metsimaholo local municipality (Metsimaholo means "big water")}

The area forms the north eastern part of the region, with the Vaal River forming the northern boundary. The Vaal Dam is located in this area. The R59 freeway connects the area with Gauteng province. The municipal main offices are located in Sasolburg. Other main urban centres are Zamdela, Deneysville/Refengkgotso and Oranjeville/Metsimaholo. The region could be classified as a "fringe" rural area, some 2 hours drive from the closest metropolitan area. Municipal departments include: Office of Municipal Manager, Financial Services, Social Services, Corporate Services, LED and Housing and Infrastructure Services. The LED unit forms part of the LED and Housing Department (Meyer, 2013).

A LED unit does exist consisting of a manager and only one LED officer. The Municipal committee for LED is operational. The Business chamber in area is operational and active. Good relations exist with provincial departments and district. The LED strategy has recently being compiled and is fully implementable. The LED section lacks of skills, capacity and leadership. Services master plans are not in place with no specific marketing plans. Leadership conflict exists within the municipal structures. Large poor areas still exist with housing backlogs. Potential exists for tourism development along the Vaal Dam and Vaal River. The municipal area is well known as a manufacturing and industrial focused cluster which includes Sasol Industries. The cluster needs to be protected and strengthened.

In terms of the 2010 COGTA (2010) turnaround strategy, the following challenges were listed for the municipal area namely poor maintenance of roads and infrastructure, no services master plans, lack of housing data base and housing development, poor management system for CDW's and ward committees in the area, high turn-over levels of staff, poor functionality of portfolio committees, poor financial management, lack of planning data and lack of an LED unit with development strategies. Solutions are listed as support by DBSA and MIG funding to development infrastructure, funding to support ward committees and CDW's, assist municipality with salary packages for top employees, national government assistance with improved financial control, and COGTA to assist with the set-up of the LED unit (COGTA, 2010).

The strategy identifies six general LED themes which needs to be focused on namely increased investment, creating clusters, promote entrepreneurship, sector development, neighbourhood renewal, and marketing of the area (Metsimaholo LM, 2011). The strategy continues on the general trend by the listing of three programme areas as listed below (Metsimaholo LM, 2011):

Programme area 1: Business competitiveness.

Programme area 2: Skills and human development.

Programme area 3: Community economic regeneration. 


\subsection{Ngwathe local municipality (Ngwathe means "Renoster River")}

This area forms the northern and central area of the region. The N1 freeway, which links Johannesburg with Cape Town, bisects the area and a main physical feature is the Vredefort Dome and the Vaal River. The municipal offices are located in Parys/Tumahole. Other urban centres include Heilbron/Phiritona, Koppies/Kwawatsi, Vredefort/Mokwallo and Edenville/Ngwathe. The region could be classified as a "fringe" rural area, some 2 hours drive from the closest metropolitan area. Municipal departments include: Office of Municipal Manager, Financial Services, Community and Emergency Services, Corporate Services, and Infrastructure Services. The LED unit forms part of Community Services (Meyer, 2013).

A LED unit exists of an acting LED Manager with two LED officials. A number of community projects are currently implemented with success and the municipal LED committee is operational. Business chambers exist in Parys and Heilbron and are very active. Good links exist between the municipality and the district municipality. The LED strategy was internally updated during 2013 and is fully implementable. Services master plans are outdated and need to be updated. No formal marketing plan exists for the municipal area. Space is currently available for industry development. Potential exists for commonages development due to the strong agriculture sector. Partnerships, such as a development forum, needs to be created in order to improve coordination and cooperation. Skills development projects are required. The municipal area is well located along the N1 and R59 freeways. Potential exists for tourism in townships, SMME development and development of industries in Koppies and Heilbron (Meyer, 2013).

In terms of the 2010 COGTA (2010) turnaround strategy, the following challenges were listed for the municipal area namely poor maintenance of roads and infrastructure, no services master plans, lack of housing data base and housing development, poor management system for CDW's and ward committees in the area, high turn-over levels of staff, poor functionality of portfolio committees, poor financial management, lack of planning data and lack of an LED unit with development strategies. Solutions are listed as support by DBSA and MIG funding to development infrastructure, funding to support ward committees and CDW's, assist municipality with salary packages for top employees, national government assistance with improved financial control, and COGTA to assist with the set-up of the LED unit (COGTA, 2010).

The LED strategy listed the following key LED interventions as building of the institutional capacity in the LED unit, job creation through infrastructure development, inclusion of the disadvantaged communities in the local economy, creation of an enabling local economic environment, investment and promotion of tourism and heritage development, skills development and assistance to SMME's. Economic sectors of importance are listed as manufacturing, mining, construction, tourism, agriculture and SMME development (Ngwathe LM, 2007).

LED units at the various municipalities in the study area lack capacity, funding, skills and qualified and committed officials. Furthermore, LED units and officials are isolated in terms of physical locality and institutionally from top management. It would seem that the LED function at municipalities in the region is an "unfunded mandate". Solutions are provided in the next section of the article.

\section{Solutions}

\subsection{General aspects}

Local government's overarching role in development is to provide an enabling environment for all its residents and businesses to prosper. In order to achieve this requirement, local government needs to have a LED strategic plan which has a balanced approach between "pro-poor" and "pro-growth". LED strategies need to intervene in the creation of jobs, poverty alleviation and the general improvement of quality of life. LED is a strategic process which stimulates good governance, cooperation and partnership development. It can also support management and administrative functions. LED is "everybody's business", including all levels of government, the local communities and business people, as it is a cross-cutting issue (refer to Figure 1). LED success requires strong and committed local leaders and local LED "champions".

Local leadership is critical and essential for LED success. The term "local leadership" includes members of the "LED triangle" of local stakeholders. Government leaders are expected to take the lead in coordination and facilitation, but other leaders from the community and business must contribute. Under the term "local leadership", two other terms are also listed namely "local champions" and "local drivers". Local leaders and champions must work together as partners to maximize local resources and actions. Local leaders must make sure the local economy is driven and to create momentum. Local government must take quick and effective decisions to the benefit of the local community. Local 
leaders must put communities first and facilitate participation by all stakeholders. Examples of local champions are local government officials such as the municipal manager, and LED manager, local politicians such as the mayor and ward councillors, local ward committee members and CDW's, local business leaders, non-governmental organizations (NGO's) leaders and church leaders. Political instability can have a significant negative impact on LED.

A potential dynamic driving force behind LED initiatives is partnership formation by local stakeholders. Local developmental projects driven by local business and local communities have more chance to succeed than projects attempted by government alone. Local people must play a leading role in local initiatives. Local regional development occurs through local coordination. Local partnership formation leads to improved self-governance by communities.

The current municipal LED unit standard structure is insufficient due to the fact that LED is not a cross-cutting municipal function. The LED function must therefore be driven by all municipal departments in an integrated manner. This lack of a cross-cutting approach to LED fails to provide communities with diversified economic opportunities. Only those LED projects which affects a single municipal entity are attempted to be implemented. This type of implementation has resulted in small community development projects, with limited economic impact. The municipal LED process has so far not being successful in linking "big" business with SMME's. LED units usually think and plan on a small scale. The current system of LED implementation has the following implications: No skills transfer to SMME's occurs, senior managers are appointed from outside the area and are not committed to the municipal area because they resides somewhere else, projects benefit outside people and businesses and not locals, and local communities and small business becomes antagonistic towards municipal officials as outsiders in their own back yard (Malefane, 2009).

Local municipalities could make a larger impact on local economies by utilizing LED as an integral part of their overall planning as part of service delivery (Human et al, 2008). An integrated use of LED by local government was introduced in the White Paper on Local Government (Republic of South Africa, 1998) as well as in the Municipal Systems Act (Republic of South Africa, 2000). Figure 3 is a summary of the integrative process as proposed.

Figure 3: Integration of the LED function at the local government sphere

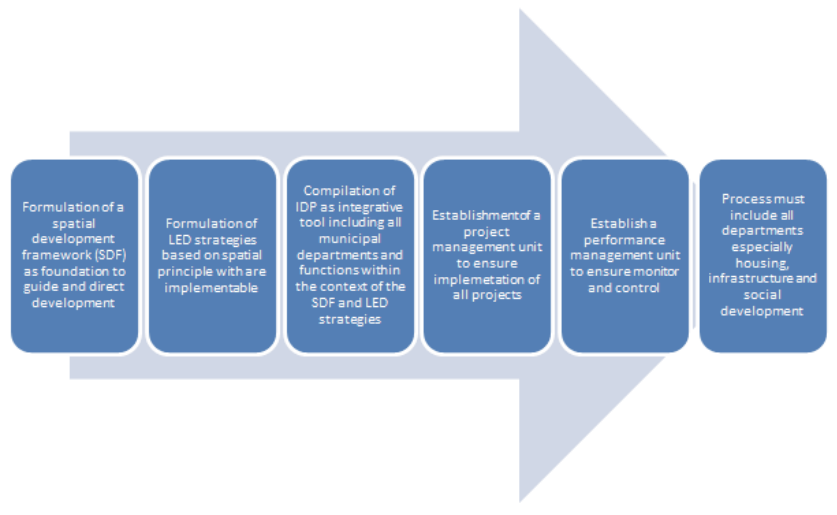

Source: Meyer, (2013).

A progressive policy and legal framework does not however guarantee successful LED process and implementation. For LED to be effective, appropriate institutional arrangements must exist within municipalities to take the laws and policies and transform them into locally meaningful interventions in collaboration with all relevant stakeholders/actors.

The establishment of LED units at all local municipalities in the region in terms of capacity, skills and position in the municipal structure is priority. Introductory LED skills training for all councillors and senior officials to create improved awareness are proposed. CDW's are a key component of LED implementation. Such officials need to be more involved in the LED units and need specialized training. Ward committees, in conjunction with CDWs need to be fully operational and have to be trained in the basic concepts of rural development and LED. Municipal LED portfolio committees need to be fully functional with regular meetings, driven by the LED unit.

The establishment of an integrative workgroup between the LED unit, the housing unit and the town planning section is proposed. Spatial planning initiatives such as the spatial development framework (SDF) need to be part of implementation. This will ensure focused development nodes and corridors in the region. The compilation of marketing 
plans for each of the local municipalities are needed, as no such plans exist. Such marketing plans should focus on competitive advantages (agriculture, mining, manufacturing and tourism) to attract, remain and expand businesses, formulation of incentives regarding land, tax rebates, etc linked to IDZs and annual "early warning system" (EWS) surveys to determine the needs of local businesses. Local government must assist in the improvement and strengthening of external business structures such as business chambers in the area. Facilitate the establishment of a community organizations forum for the region, including all NGO's in order to support community projects.

\subsection{Generic LED strategies}

As a result of ongoing research and practical policy formulation done in the study field by the author since 1994, the following generic LED strategies are proposed to be included in any LED strategy. Although a "one-size-fits-all" approach is not promoted, these generic strategies will give direction to the LED practitioner in both urban and rural settings (Meyer, 2013)

Strategy 1: Strengthening of internal and external institutional structures and processes.

Strategy 2: Strengthening and support of the agricultural sector.

Strategy 3: Ensure optimal linkages and support to the mining sector.

Strategy 4: Strengthening and support of the manufacturing sector.

Strategy 5: Ensure optimal development of the "Green economy".

Strategy 6: Ensure accelerated tourism development.

Strategy 7: Ensure optimal opportunities for development of the informal sector.

Strategy 8: Support and development of entrepreneurship and small business development.

Strategy 9: Support and development of education and skills development.

Strategy 10: Ensure infrastructural development.

Strategy 11: Provision of basic needs and social development.

\subsection{Enabling environment for LED implementation}

One of the main functions of LED is to create an enabling environment for economic development and for the private sector to prosper. A total of twelve factors were identified by Meyer (2014) in order to create an enabling local development environment which include: Public-private partnership creation, clear and implementable developmental policies, strong local leadership, poverty alleviation and social development initiatives, economic development initiatives, environmental and spatial development actions, infrastructure development, human resource development, entrepreneurial development, transport and access opportunities, agricultural opportunities, and a safe and secure environment.

\subsection{Job creation and LED}

The central theme of LED is the creation of jobs. A job creation plan could include aspects such as the establishment of a central employment agency with a data base, mentorship programmes, public works programmes, intensive technical and business skills training, development of incubators and job centres, youth development programmes and policy formulation with incentives for job creation.

\section{Lessons for LED Implementation}

The following sessions in LED policy formulation, planning and implementation are listed:

Strategic approach: Municipalities have not succeeded in the integration of LED with the overall IDP processes. SMME support exists on ad hoc basis, but no comprehensive economic or sectoral analysis exists at most municipalities. Wide and vague statements such as SMME development, skills development, improve business conditions are listed with no detail. A concept such as local diversification means nothing if not grounded with detailed plans.

Poverty alleviation: In most cases LED is "downgraded" in stature as only poverty alleviation projects and community projects. Pro-poor focus alone will not lead to successful LED implementation. A balance is needed between market initiatives, job creation and pro-poor actions. Poverty alleviation forms more part of social development than LED.

Implementation systems: Although strategies are formulated, no implementation plans or structures are in place. Local business support is only limited to local procurement. Implementation plans are dependent on human resources 
and funding. External funding requires skills and expertise on how to lobby for such funding.

Partnerships: Successful LED occur where government and businesses work together to improve the economy of a specific area. Business has not really been included in IDP or LED in the planning and implementation of strategies. Poor partnerships have led to limited LED success. Only small community development projects have been attempted.

Regional co-operation: No regional or district co-ordination exists between district municipality and the local municipalities. Regional co-operation and alignment is of key importance where the economies can complement and support the region.

Project sustainability: Projects have not been started due to lack of funding. Municipal projects need to focus on LED outcomes. For example, labour intensive projects could cost more and take more time to complete, without additional income to municipality. Most projects are therefore not sustainable.

LED and political considerations: Politicians have a say in the prioritisation of projects. Projects that are visible with immediate income, outcome, regardless of sustainability are selected. The most important economic sector, for example agriculture, is not prioritised.

Capacity: No real skills development has taken place. Officials are left to manage projects without business, financial or project management skills.

Institutionalisation: LED projects are scattered throughout a specific municipality, with no single department or unit as coordinator. This fact renders most LED strategies irrelevant. LED strategies need to be spatially grounded.

Finally an LED strategy must be diverse and not based on a few projects. Identified projects must be based on local demand (Rogerson, 2009).

\section{Conclusions}

In conclusion, the following challenges exist regarding the LED process from policy to implementation at the local government sphere. These include that policy doesn't automatically lead to implementation, improved skills levels are required, staff and funding shortages need to be resolved, poor community involvement in the planning and implementation of LED projects exist and poor monitoring and evaluation (Nel \& Rogerson, 2005). Municipalities in South Africa do not have adequate economic strategies in place to address the issues of poverty, unemployment and inequality (SACN, 2004). LED is currently still not a priority at most local authorities, and limited funding is made available from national government. LED strategies lack detail for interventions and lack monitoring and evaluation. Small rural municipalities especially struggle to implement LED. The role and functions regarding LED is vague with a lack of willingness for partnerships with the private sector (Khanya-Aicdd, 2006).

LED is not yet well embedded in municipal structures, which is shown by the lack of LED units within the five municipalities analysed and also by the limited funds and in some instances no funds allocated to LED. LED has as its goals to create local jobs, to ensure economic stability and diversity, build on comparative advantages, assist the poor, and ultimately strive to improve the quality of life of all local communities. Local commitment, adequate skills and capacity is however non-negotiables for LED success.

\section{References}

Acts see Republic of South Africa.

Australia South Africa Local Government Partnership (ASALGP). 2005. A handbook for provincial and municipal elected and appointed officials about local economic development. Web access: www.devplan.kzntl.gov.za/ASALGP. Date of access: 21 Feb 2013. Brisbane. Australian Government.

Bartik, T.J. 2003. Local economic development policies. Kalamazoo. Michigan. Upjohn Institute Staff Working Paper No. 03-91.

Blakely, E.J. 1994. Planning local economic development: theory and practice. Newbury Park: Sage.

Blakely, E.J., \& Bradshaw, T.K. 2002. Planning local economic development: Theory and practice. $3^{\text {rd }}$ edition. California. Sage Publications.

Department of Cooperative Governance and Traditional Affairs (COGTA). 2010. Municipal turn around strategies report for Fezile Dabi District Municipality. Pretoria. Government Printer.

Department of Provincial and Local Government (DPLG). 2003. Local economic development: A resource book for municipal councilors and officials. Pretoria. Government printer.

Department of Provincial and Local Government (DPLG). 2005. Policy guidelines for implementing local economic development in South Africa. Pretoria. Government Printer.

Department of Provincial and Local Government (DPLG). 2006. LED framework: Stimulating and developing sustainable local economies. Pretoria. Government Printer.

Fezile Dabi District Municipality. 2011. Spatial development Framework. Sasolburg. 
Fezile Dabi District Municipality. 2012. Integrated development plan 2011-2012. Sasolburg.

Human, F., Lochner, M. \& botes, L. 2008. Marketing Plans against all odds: LED in small towns of the Free State Province, South Africa. Africa Insight, Vol 38 (1). June 2008.

Institutional Institute for Environment and Development (IIED). 2000. Rural planning of South Africa: A case study. London. Web access: www.iied.org. Date of access: 10 August 2013.

International Labour Organization (ILO). 2006. A Local Economic Development Manual for China, ILO, Geneva.

Khanya-AICDD. 2006. Investigating pro-poor local economic development in South Africa. Briefing no 1, April 2006. Bloemfontein.

Lewis, W.A. 1966. Development Planning: The essentials of economic policy. London. Manchester School.

Local Government Support Program in ARMM (LGSPA). 2009. Strategic local economic development: A guide for local governments. Davao City, Philippines.

Mafube Local Municipality. 2012. Local Economic Development Strategy. First Draft. Frankfort.

Malefane, S.R. 2009. Structuring South Africa Municipalities for effective LED implementation. Journal of Public Administration. Vol 44 no.1. p 156 to 168, April 2009.

Metsimaholo Local Municipality. 2011. Metsimaholo Local Economic Development plan. Sasolburg.

Meyer, D.F. 2013. An exploration of solutions for rural development: The case of the northern Free State. NWU: Vaal campus. Vanderbijpark (PhD thesis).

Meyer, D.F. 2014. Local government and the creation of an enabling developmental environment. Administratio Publica, Vol 22 no 1, p 24 to 46, March 2014.

Meyer-Stamer, J. 2003. Stimulating rural enterprise in South Africa: Lessons from LED. Paper presented at conference on 21-23 May 2003. Web access: www.mesopartner.com. Date of access: 13 September 2013.

Meyer-Stamer, J. 2008. Systemic Competitiveness and local economic development. Web access: www.mesopartner.com. Date of access: 13 September 2013.

Moqhaka Local Municipality. 2010. Moghaka Local Municipality IDP 2011/2012. Kroonstad.

Nel, E., \& Rogerson, C.M. 2005. Pro-poor local economic development in South Africa Cities: Policy and practice. Africa Insight, 35 (2) 5-20.

Ngwathe Local Municipality. 2007. Ngwathe Local Municipal LED. Parys.

Reich, R. 1991. The work of nations. New York. Vintage.

Republic of South Africa. 1996. Constitution of the Republic of South Africa as adopted by the Constitutional Assembly on 8 May 1996. ISBN: 0-260-20716-7. Pretoria. Government printer.

Republic of South Africa. 1998. White paper on Local Government. Development of Constitutional Development. Pretoria. Government Printer.

Republic of South Africa. 2000. Municipal Systems Act, no 32 of 2000. Pretoria. Government printer.

Rodrigues-Pose, A. 2001. The role of ILO in implementing local economic development strategies in a globalized world. London School of Economics. Unpublished paper.

Rogerson, C.M. 2009. Strategic Review of local economic development in South Africa. Final report submitted to Minister S Shiceka of Department of Development Planning and Local Government (DPLG). Commissioned by DPLG and GTZ. May 2009.

Scheepers, T. \& Monchusi, P. 2002. Implementing the law relating to local economic development in the struggle against poverty. Seminar Report 14. Johannesburg: Konrad Adenauer Stiftung.

Sekhampu, T.J. 2010. An investigation into the economic sustainability of Kwakwatsi. NWU: Vaal campus. Vanderbijlpark. (PhD thesis).

Soedjatmoko, M.1985. The primacy of freedom in development. University Press of America.

South African Cities Network (SACN). 2004. State of the Cities Report 2004. Johannesburg. SACN.

Swinburn, G., Goga, S., \& Murphy, F. 2006. Local Economic development: A primer developing and Implementing local Economic development strategies and action plans. Washington. The World Bank.

Triegaardt, J.D. 2007. Assessing local economic development and social welfare benefits in a globalised context. Web access: www.dbsa.org/Research/Documents/Assessing\%20local. Date of access: 12 September 2013.

Trousdale, W. 2005. Promoting Local Economic Development through strategic Planning: The local Economic Development Series, Volumes 1 to 5. Nairobi. Kenya. UN-Habitat

Van Der Heijden, T. 2008. Key issues in local economic development in South Africa and a potential role of SALGA. Unpublished report prepared for SALGA.

Venter, A. 2014. Interview with Dr A Venter, Deputy LED manager, Fezile Dabi District Municipality. Date of interview: 12 December 2011 and 4 April 2014

World Bank. 1991. World development Report. Washington. 